coral limestone, which forms but a comparatively thin crust, and has been altogether removed from most of the higher regions by sub-aërial agencies. However, I have observed the raised coral rock still preserved at considerable heights above the sea, and in two localities at elevations of 900 feet.

"Amongst the sub-group known as the Shortland Islands, I came upon beds of this impure calcareous rock (beneath the raised coral rock) abounding in Pteropods, mostly Hyalca, and large foraminiferous tests, mingled with shells, some of them of shallow water babit.

$$
\text { "I am, \&c., "H. B. GuPPY" }
$$

\section{A FORGOTTEN EVOLUTIONIST}

A

BOOK has lately come into my hands a few words about which may possibly interest some of the readers of NATURE. Its title is "Histoire Naturelle des Fraisiers" ; the author was A. N. Duchesne, and it was published at Paris in 1766 . It must be, I suspect, an uncommon book, for there is no copy in the library of the Royal Gardens at Kew. And this library, comprising as it does the contributions of many collectors who allowed little to escape them, is remarkably complete; $\mathrm{Mr}$. Daydon Jackson has in fact found in it more than a thousand publications the titles of which are not to be met with in the last edition of Pritzel's well-known "Thesaurus."

The scarceness of a botanical book is not perhaps in itself a matter of any great moment, and I bought the book out of a provincial sale catalogue without expecting it to be particularly interesting, though I knew Duchesne's name as an authority on the cultivated forms of the strawberry. I very soon, however, came to the conclusion on looking over it that it was a very remarkable production indeed, and in a scientific sense at least a century in advance of its time.

Duchesne's book is in fact the record of a purely biological study of a small group of plants. The significance of work of this sort has only been thoroughly recognised since the publication of the "Origin of Species." Just as with C. K. Sprengel, whose book was also written in the last century (1793), the world has had to roll on far into another hundred years before it was ready to do justice to this kind of research. There is a curious incongruousness between the freshness and modernness of the ideas and the faded type and musty paper in which they are embalmed.

Duchesne plunges at once into the business of his book in the first line of the preface with a straightforward simplicity not unworthy of Mr. Darwin. I will attempt a translation of the first paragraph :--

"The wish to see if it were possible to raise from seed a plant which scarcely ever produces any has led me by a happy chance to the production of a new race, which made its appearance at Versailles in $176 \mathrm{r}$. This circumstance induced me to more closely devote myself to the study of strawberries, and led me to another discovery. I found that they are not all truly hermaphrodite; forms exist, in fact, which are sexually differentiated. ${ }^{1}$ And I have succeeded in the past year, 1765 , in fertilising, by means of one set of plants, individuals of another sort, which are cultivated as a matter of curiosity, and are constantly sterile. One, amongst others, has produced fruits of great beauty; M. le Marquis de Marigny has obtained for me the honour of having this submitted to the king, and it is to be raised in the Versailles Gardens by my method. This unexpected success has still more redoubled my ardour to make further observations."

The race so produced, which Duchesne called Le Fraisier de Versailles, or Fragaria monophylla, is un-

$\mathrm{r}$ This must be one of the first observations of the tendency of plants
with hermaphrodite flowers to with hermaphrodite flowers to pass into the dicesious state. The fact is now well established. (See Darwin's "Forms of Flowers," pp. 278-309.) doubtedly a very curious plant. All its leaves are permanently unifoliate; i.e. instead of bearing three leaflets, as is ordinarily the case with strawberries, the petioles bear but one. Duchesne observes that this is also the case with the first leaves of all seedling strawberries. Fragaria monophylla may be therefore regarded as a form which always retains the juvenile, and never arrives at the adult, foliage, and this peculiarity remains constant in subsequent generations. The effect of crossing, as a potent stimulus to variation, could not but have powerfully impressed Duchesne in so striking a case as this, and further observations seemed to have led him to account for the common characters which otherwise diverging forms exhibited as best accounted for by a common ancestral origin. The study of geographically separated species, however, necessarily led him to see that something more than crossing was needed to account for variation in every case. In discussing Fragaria virginiana, a native of North America, which is the origin of the race of Scarlets, Duchesne speculates as to its derivation from the wild $F$. vesca of Europe, and attributes the divergences from this type to tie effect of North American soil and climate.

His work on Strawberries, where he was dealing mainly with races, led him to speculate with regard to the higher groups of species, genera, and orders. His results seem to me, for the time, so extraordinarily bold, and therefore historically so interesting, that I quote the first portion of the Recapitulation, pp. $219^{-22}$, entire, in the original French :-

"J'âi déjà dit, à l'occasion du Fraisier-ananas, qu'il étoit très-difficile de ranger en ligne droite les diverses Races d'une même Espèce, de manière qu'on pût passer de l'une a l'autre par gradations de nuance. Cela est peut-être aussi impossible, que de ranger en ligne droite les Espèces, les Genres, et les Familles; par la raison que chaque Race, comme chaque Espèce, chaque Genre, ou chaque Famille, a des rapports de ressemblance avec plusieurs autres.

"L'ordre Généalogique est donc le seul que la nature indique, le seul qui satisfasse pleinement l'esprit; tout autre est arbitraire et vide d'idées. J'ai eu soin, à chacune des Races de Fraisiers, d'indiquer ce qui m'a paru vraisemblable à cet égard; mais je n'ose me flatter d'avoir toujours rencontré juste. Il faudroit, pour le bien faire, avoir des connaissances certaines et précises du pays natal de chaque Fraisier, ou bien, du tems où il a été élevé de graine, et de quel autre Fraisier provenoit cette graine; j'ai fait voir combien on manquoit encore de lumières sur tout cela.

"C'est par cette raison que je me suis permis de donner mes conjectures; en voici les résultats ; la forme d'Arbre généalogique les rendra encore plus sensibles, et en fera mieux saisir l'ensemble."

It is certainly startling to come upon a phylogeny of the most modern type-in a book more than a century old.

It was not till after I had gratified myself with a study of Duchesne's remarkable speculations that it flashed across my mind that attention had already recently been called to them ; and I found, in fact, that Prof. Alphonse de Candolle, in a short paper put together with the felicitous erudition of which he seems to possess so inexhaustible a store, had already, in May of last year, ${ }^{1}$ stated most of the points on which I have dwelt above. And he mentions that, on the occasion of a visit to Mr. Darwin in 1880 he told him of the existence of the book, which be describes, justly enough, as "a very curious work, older than that of Lamarck, but to which no one had ever referred except for points of secondary interest."

I know little about Duchesne himself. De Candolle says that he was a horticulturist and Professor of Natural History, and that his knowledge was as varied as it was I "Darwin corsidéré au point ce vue des causes de son succès," \&c. Archives des Sciences, May, 1582 . 
sound. No one, nevertheless, ever seem; to have paid the smallest attention to his evolutionary theories. Even Silvestre, who pronounsed his éloge at a public meeting of the Société Royale d'Agriculture in I827, a bstains from the slightest reference to them.

While in his experiments and his mode of drawing conclusions from them Duchesne strongly recalls the method of Mr. Darwin, the parallel cannot be carried further. In so far as he obtained a glimpse at the molern doctrine of evolution it was in the form afterwards formulated by Lamarck. Of the part played by the struggle for existence in the matter I find no trace in his writings.

W. T. THISELTON DYER

\section{TEACHING ANIMALS TO CONVERSE}

MR. DARWIN'S notes on Instinct, recently published by my friend Mr. Romanes, have again called our attention to the interesting subject of instinct in animals.

Miss Martineau once remarked that, considering how long we have lived in close association with animals, it is astonishing how little we know about them, and especially about their mental condition. This applies with especial force to our domestic animals, and above all of course to doss.

I believe that it arises very much from the fact that hitherto we have tried to teach animals rather than to learn from them,-- to convey our ideas to them, rather than to devise any language, or code of signals, by means of which they might communicate theirs to us. No doubt the former process is interesting and instructive, but it doesinot carry us very far.

Under these circumstances it has occurred to me whether some such system as that followed with deafmutes, especially by Dr. Howe with Laura Bridgman, might not prove very instructive if adapted to the case of dings.

Accordingly I prepared some pieces of stout cardboard, and printed on each in legible letters a word such as "Food," "Bone," "Out," \&c. The head master of one of the deaf and dumb schools kindly agreed to assist me. We each began with a terrier puppy, but neither of us obtained any satisfactory results. My dog indeed was lost before I had had him long. I then began training a black poodle, "Van" by name, kindly given me by my friend Mr. Nickalls. I commenced by giving the dog food in a saucer, over which I laid the card on which was the word "Food," placing also by the side an empty saucer, covered b: a plain card.

"Van" syon learnt to distinguish between the two, and the next stage was to teach him to bring me the card; this he now does, and hands it to me quite prettily, and I then give him a bone, or a little fuod, or take him out, according to the card brought. He still brings sometimes a plain card, in which case I pint out his error, and he then takes it back and changes it. This however does not of ten happen. Yesterday morning, for in stance, "Van" brought me the card with "Food" on it, nine times in succession, selecting it from among other plain cards, though I changed the relative position every time.

No one who sees him can doubt that he understands the act of bringing the card with the word "Food" on it as a request for something to eat, and that he distinguishes between it and a plain card. I also believe that he distinguishes for instance between the card with the word "Food" on it and the card with "Out" on it.

This then seems to open up a method, which may be carried much further, for it is obvious that the cards may be multiplied, and the dog thus enabled to communicate freely with us. I have as yet, I know, made only a very small beginning, and hope to carry the experiment much further, but my object in sending this communication is $t w o f o l d$. In the first place I trust that some of the readers of NATURE may be able and willing to suggest extensions and improvements of the idea.

Secondly, my spare time is small and liable to many interruptions; animals also we know differ greatly from one another. Now many of your readers have favourite dogs, and I would express a hope that some of them may be disposed to study them in the manner indicated.

The observations, even though negative, would be interesting; but I confess I hope that some positive results might follow, which would enable us to obtain a more correct insight into the minds of animals than we have yet acquired.

High Elms, Down, Kent, December 20, I 883

\section{THE FRENCH DEEP-SEA EXPEDITION $O F$ I 883}

I HAVE just returned from a very short visit to Paris, made for the purpose of inspecting the Mollusca which were procured during last summer's deep-sea expedition in the French Government steamer Talisman. The expedition was under the scientific charge of Prof. Alphonse Milne-Edwards. For the opportunity of this inspection I was indebted to the kindness of my friend Dr. Paul Fischer, whose reputation as a conchologist is so well known.

The course of the expedition was along the Atlantic coasts of Spain, Marocco, Sahara, Senegal, Cape Verde Isles, the Canaries, and Azores; and the time occupied was three months. More full and accurate particulars will very shortly be given by Prof. A. Milne-Edwards to the Academy of Sciences, and be published in their Comptes Rendus. The collection will be exhibited next month to public view. The greatest depth explored was about 2200 fathoms. The trawl was mostly used. Life was plentiful everywhere. As was the case in the Porcupine, Challenger, and other expeditions of the same kind, many animals (especially Crustacea) at the greatest depths were highly and brightly coloured, some of them having large eyes, and others being blind or eyeless. There was an abundance of hitherto unknown forms (genera and species) in every department of zoologyfishes, Mollusca, Polyzua, Crustacea, Annelids, Ecbinoderms, Polyps, Corals, Foraminifera, and Sponges Among the Mollusca were some remarkable cases of the wide distribution of species in respect of space as well as of depth. For instance, boreal shells, such as Fusus islandicus and $F$. berniciensis, which inhabit northern seas at moderate depths, viz. 50 to 80 fathoms, were found living off the coast of Marocco, and the latter species even below the tropic of Capricorn, at depths of from 450 to 2200 fathoms. Lima excavata, considered a peculiarly Norwegian species, was likewise obtained off the Moorish coast, of a very large size; it was recorded by Prof. Seguenza as a Pliocene fossil of Sicily and Calabria, under the name of Lima gigantea. In the Porcupine Expedition of 1870 fragments were dredged off Cape St. Vincent; and in the Challenger Expedition this fine species was obtained from io to 175 fathoms off Western Patagonia and Japan. A bivalve (Scrobicularia longicallus), which in northern seas inhabits moderate depths, was procured in many places by the Talisman, at depths varying from 350 to 1429 fathoms. It occurred living in the deepest dredgings of the Porupine Expedition of 1869 , off the coast of Brittany, at a depth of 2435 fathoms. Many Mollusca (e.g. Pecten vitreus, Limopsis minuta, Dentalium agile, Trochus ottoi, Columbella haliceti, and Scaphander punctostriatus) seem to inhabit the depths of the North Atlantic in every part, from one side to the other. The smaller shells in the Talisman collection have not yet been picked out. The Marquis de Folin will, with his usual care and industry, undertake that part of the work, which will occupy some time; he has requested me to examine and name those species which 